Thomas Laminger ${ }^{1 *}$, Gerd Mauschitz ${ }^{1}$, Dunja Sokolovic ${ }^{2}$, Wilhelm Hoeflinger ${ }^{1}$

${ }^{1}$ Vienna University of Technology, Institute of Chemical Engineering, Vienna, Austria, ${ }^{2}$ University of Novi Sad, Faculty of Technical Sciences, Novi Sad, Serbia
Scientific paper ISSN 0351-9465, E-ISSN 2466-2585 UDC:685.763.067.4 doi: $10.5937 /$ ZasMat1704425L

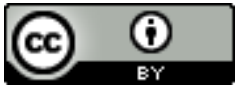

Zastita Materijala 58 (4) $425-431(2017)$

\title{
Influence of the test emulsion on filtration efficiency and pressure drop of mist Separators for cooling lubricants
}

\begin{abstract}
This work deals with standardized filter tests of mist separators for cooling lubricants aerosols. The Austrian standard ÖNORM Z1263 describes a filter test rig and test procedure for standardized comparable filter tests and futher for a classificiation.

Following this guideline six industiral used filter elements with different designs and materials were tested to determine filtration specific parameters like the pressure drop, total liquid holdup, oil holdup and separation efficiency. Finally, filter elements will be classified by their separation efficiency into a filter-class from 1 to 10.

The ÖNORM Z1263 does not give any specific test substance, so there is an interest to study the influence of various coolant oils as used in industry.

Therefore for the filter test, three different coolant oils were used as test substance: mineral oil, semi-synthetic oil and full-synthetic oil. The six filter elements have been tested according to the guideline to reach a steady-state liquid equilibrium within 2-4 hours.

Comparing the results of the steady-state pressure drop, total holdup and oil holdup as well as the separation efficiency in four particle size ranges there was no significant influence of the test oil base found. The achieved filter-class numbers differ only by one number.
\end{abstract}

Keywords: Coolant oil, emulsion, filter elements, separation efficiency, pressure drop, filter testing.

\section{INTRODUCTION}

For precise and fast metal working process, e.g. cutting, drilling, grinding..., cooling lubricants are essential. These lubricants, pure oils or wateroil-emulsions, are used for cooling and lubrication of workpiece and working tool. $50 \%$ and more of the cooling lubricants are used as emulsions [1]. The oils are either mineral, semi-synthetic or fullsynthetic ester oils and consist further of several ingredients (emulators, anti-foam-agents, stabilizer, pesticides...).

The cooling lubricants are typically sprayed onto the working tool, whereas the high rotation velocity generates fine droplets and vapor. Depending on the working issue, the droplet emissions can be very high up to several hundreds of $\mathrm{mg} / \mathrm{m}^{3}$ [2].

\footnotetext{
${ }^{*}$ Corresponding author: Thomas Laminger

E-mail: thomas.laminger@tuwien.ac.at

Paper received: 29. 05. 2017.

Paper accepted: 17. 08. 2017.

Paper is available on the website:

www.idk.org.rs/journal
}

State-of-the-art workshops are fully enclosed and the aerosol becomes sucked-off and filtered by a mist separator. Mist separators can be filtering separators, electrostatic precipitators, scrubbers, inertial separators and packed bed filter systems. About 40 to $50 \%$ are filtering separators [3]. Such apparatus consists typically of several filter elements of different material fineness, respectively separation efficiency, in series.

The droplets sucked-through these filters are partially separated from the air and form a liquid phase inside the filter ("liquid holdup"). With ongoing separation, the formed liquid is draining-off ("drainage"). Coarse filter (baffle plates, wire mesh...) have a comparable low liquid holdup level and the pressure drop increase by the liquid phase is very low. Filter elements consisting of fine fibres, e.g. coalesce-filter, HEPA-filter..., can have a very high liquid holdup with enormous pressure drop increase $[4,5]$.

The time to reach a stationary behavior with constant pressure drop, separation efficiency and liquid holdup depend on material, oil properties, aerosol concentration etc. [6-9]. A first approach to 
compare the behavior of such mist separator filter elements by a standardized procedure gives the Austrian standard ÖNÖRM Z1263:2013 [10]. This national standard describes the test methods, test rig, the generation of test aerosol, the methodology for measuring the separation efficiency and classification of filter elements per their separation efficiency. As test substance, the ÖNORM is open for any coolant liquid emulsion with a maximum of $15 \%$ oil concentration.

In this work the influence of different oil bases (mineral, semi-synthetic or full-synthetic ester oils) on the behavior of six different industrial used filter elements is investigated according to the ÖNÖRM Z1263. Following the given test procedure, the filter elements are converted to a steady-state where the stationary pressure drop, separation efficiency and liquid holdup is determined. The measured results should be used for comparing finally the filter element's classification by their steady-state separation efficiency of four particle size ranges $<0.3 \mu \mathrm{m}, 0.3-1 \mu \mathrm{m}, 1-3 \mu \mathrm{m}$ and $3-10 \mu \mathrm{m}$.

\section{EXPERIMENTAL}

In this chapter a short description of the used filter test rig and test procedure is given. Both are fully described and standardized by the ÖNORM Z1263 [10]

\subsection{Filter test rig}

A filter test rig, according to the ÖNÖRM Z1263 consisting of an aerosol generator, a horizontal piping system with filter holder and a blower was build (Fig.1).

The aerosol generator has a rotating toothed head which is flooded by an emulsion squirt. Due to the high rotation speed (up to $30000 \mathrm{rpm}$ ) fine droplets are generated with droplet size range below $10 \mu \mathrm{m}$ [11].

The filter holder is suitable for square filter elements of $20 \times 20 \mathrm{~cm}$ (see chapter "filter media"). Online measurement systems for the differential pressure drop of the filter element, for the measurement of the droplet and vapor concentration of the MWF-mist emission ("CYCLEFID") [12,13], for the air volume flow, the liquid drainage flow and the oil concentration of the emulsion tank and the drainage are installed.

Furthermore, an "ageing nozzle", consisting of a ring-shaped tube with fine holes, allows high flow rates of emulsion sprayed onto the filter. With such high flow rates, it is possible to bring the tested filter in a steady state condition within a very short period ("accelerated filter ageing") [14].

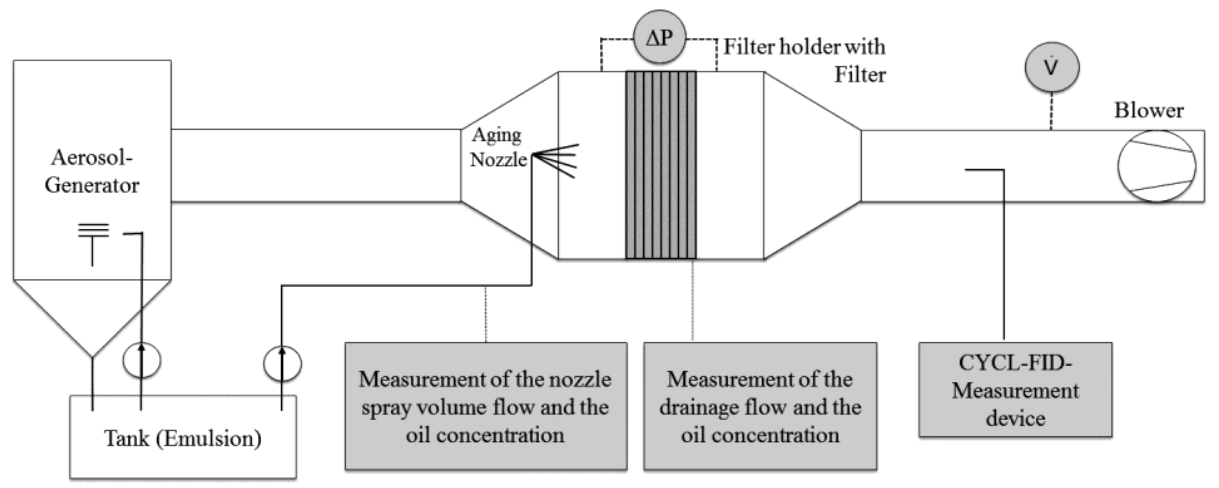

Figure 1. Schematically drawing of the filter test rig

Slika 1. Šematski prikaz uređaja za testiranje filtera

\subsection{Test procedure}

The ÖNÖRM Z1263 describes a test procedure to reach a steady state equilibrium of a wetted filter element within a short time: bringing a relative high emulsion mass flow (several $\mathrm{ml} / \mathrm{min}$ ) onto the filter element by the aging nozzle, the filter can be fully wetted within minutes or hours. This procedure allows to determine at the liquid equilibrium point the total liquid holdup, the oil holdup, the pressure drop and the separation efficiency of the tested filter media.

By balancing the emulsion flows sprayed onto the filter element and draining-off vertically down of the filter element, the total liquid holdup is calculated. Including the oil concentration of the emulsion gives the oil holdup.

During the whole test procedure, a constant air flow of is sucked-through the apparatus. Pressure drop and emulsion mass flows are recorded continuously, whereas the separation efficiency is determined before and after reaching the steady state equilibrium.

For a classification of the tested filter media the ÖNÖRM Z1263 uses the steady-state separation efficiency of four particle size ranges: $<0.3 \mu \mathrm{m}, 0.3-$ $1 \mu \mathrm{m}, 1-3 \mu \mathrm{m}$ and $3-10 \mu \mathrm{m}$. A defined filter-class is connected to minimal requested separation efficiency $\left(E_{i}\right)$ in these four particle size ranges. 
Finally, the filter elements become labeled with "filter-class 1 to 10", whereas the filter-class 10 has the highest separation efficiency (see Table 1).

Table 1. Filter classes according to the ÖNÖRM Z1263 [10]

Tabela 1. Klase filtera prema standardu ÖNÖRM Z1263 [10]

\begin{tabular}{|c|c|c|c|c|}
\hline $\begin{array}{c}\text { Filter- } \\
\text { class }\end{array}$ & \multicolumn{5}{|c|}{ Minimal requested separation efficiency (\%) } \\
\hline $\begin{array}{c}\text { Particle } \\
\text { size range } \\
\text { (number } \\
\text { and limits) }\end{array}$ & 1 & 2 & 3 & 4 \\
\hline 1 & $<0.3 \mu \mathrm{m})$ & $0.3-1 \mu \mathrm{m}$ & $1-3 \mu \mathrm{m}$ & $3-10 \mu \mathrm{m}$ \\
\hline 2 & - & - & $0 \leq \mathrm{E} 3<35$ & $0 \leq \mathrm{E} 4<50$ \\
\hline 3 & - & $0 \leq \mathrm{E} 2<35$ & $45 \leq \mathrm{E} 3<55$ & $60 \leq \mathrm{E} 4<70$ \\
\hline 4 & - & $35 \leq \mathrm{E} 2<45$ & $55 \leq \mathrm{E} 3<65$ & $70 \leq \mathrm{E} 4<80$ \\
\hline 5 & - & $45 \leq \mathrm{E} 2<55$ & $65 \leq \mathrm{E} 3<75$ & $80 \leq \mathrm{E} 4<85$ \\
\hline 6 & - & $55 \leq \mathrm{E} 2<65$ & $75 \leq \mathrm{E} 3<85$ & $85 \leq \mathrm{E} 4<90$ \\
\hline 7 & $0 \leq \mathrm{E} 1<5$ & $65 \leq \mathrm{E} 2<75$ & $85 \leq \mathrm{E} 3<90$ & $90 \leq \mathrm{E} 4<95$ \\
\hline 8 & $5 \leq \mathrm{E} 1<10$ & $75 \leq \mathrm{E} 2<85$ & $90 \leq \mathrm{E} 3<95$ & $95 \leq \mathrm{E} 4$ \\
\hline 9 & $10 \leq \mathrm{E} 1<20$ & $85 \leq \mathrm{E} 2<95$ & $95 \leq \mathrm{E} 3$ & $95 \leq \mathrm{E} 4$ \\
\hline 10 & $20 \leq \mathrm{E} 1$ & $95 \leq \mathrm{E} 2$ & $95 \leq \mathrm{E} 3$ & $95 \leq \mathrm{E} 4$ \\
\hline
\end{tabular}

\subsection{Filter media}

In this work the stationary pressure drop, total holdup, oil holdup and separation efficiency in four particle size ranges $(<0.3 \mu \mathrm{m}, 0.3-1 \mu \mathrm{m}, 1-3 \mu \mathrm{m}$ and 3-10 $\mu \mathrm{m}$ ) were determined from six different filtering filter elements. These six filter elements from Reven and Scandfilter $A B$ (see Fig. 2) are a baffle plate, a wire mesh, a coarse glass-fibre filter, a fine wire/glass-fibre filter, a fine glass fibre filter and a HEPA filter. All filter elements are widely used in industry either as pre-separators and or as final stage filter element.

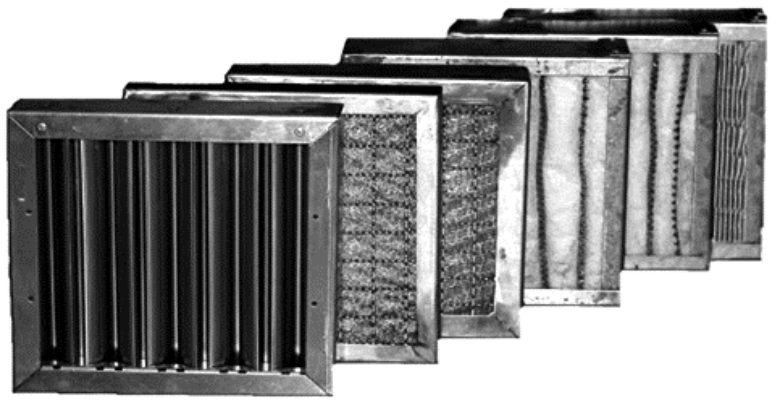

Figure 2. Tested filter elements (from left to right) Baffle plate, Wire mesh, Coarse glass-fibre filter, Fine wire/glass-fibre filter, Fine glass-fibre filter, HEPA-Filter

Slika 2. Testirani filteri (od leva na desno): plafonska ploča, žičana mreža, grubi filter od staklenih vlakana, fini žičani filter od staklenih vlakana, fini filter od staklenih vlakana, HEPA filter

\subsection{Coolant oils}

Three industrial coolant oils of OMV Austria have been used to study the influence on the stationary filter properties of the six tested filter elements. These oils, used for oil-water emulsions ( $10 \mathrm{Vol} \%$ oil in water), differ in the oil bases: a mineral oil ("Mixcut LO"), a semi-synthetic oil (“Mixcut UN2") and full-synthetic oil (“Mixcut SE"). Basic physical-chemical properties of oils are listed in Table 2. These oils form stable water-mixable emulsions.

Table 2. Properties of used oil [15-17]

Tabela 2. Karakteristike korišćenih ulja [15-17]

\begin{tabular}{|l|c|c|c|}
\hline & Mixcut LO & $\begin{array}{c}\text { Mixcut } \\
\text { UN2 }\end{array}$ & Mixcut SE \\
\hline $\begin{array}{l}\text { Mineral oil content } \\
{[\text { w\%] }}\end{array}$ & 75 & 40 & 0 \\
\hline $\begin{array}{l}\text { Density }\left[\mathrm{kg} / \mathrm{m}^{3}\right] \\
\text { ISO } 12185\end{array}$ & 884 & 965 & 994 \\
\hline $\begin{array}{l}\text { Viscosity [mm²/s] } \\
\text { ISO 3104 }\end{array}$ & 70 & 176 & 60 \\
\hline
\end{tabular}

\subsection{Test conditions}

The general test conditions for the filter tests were as follows: Three test emulsions of 20 liters of oil-water emulsions with $10 \mathrm{Vol} \%$ oil concentration each were prepared. The mixed emulsion was filled into the emulsion tank, from where the aerosol generator and the aging nozzle were supported. Rotation speed of the aerosol generator was kept constant at 7500rpm, temperature $20^{\circ} \mathrm{C}$, emulsion flow rate of $1.4 \mathrm{l} / \mathrm{min}$ for the aerosol generator, air flow through the pipe $80 \mathrm{~m}^{3} / \mathrm{h}$ or $200 \mathrm{~m}^{3} / \mathrm{h}$, depending on the manufactures data. During the accelerated aging of the filter elements, the filter loading value was $0.2 \mathrm{l} / \mathrm{min}$ until the filter reached a steady state pressure drop. Afterwards the nozzle spray was shut off and the aerosol generator kept on generating the test aerosol for determination of the separation efficiency for at least another 10 minutes.

\section{RESULTS AND DISCUSSION}

Before accumulated results of the obtained stationary pressure drop, total holdup, oil holdup and the separation efficiency in four particle size ranges of the individual filters are summed up, first a detailed result of one filter element is presented.

\subsection{Detailed results of one filter test}

To give an impression of the filter tests and the evolution of pressure drop over time during an accelerated filter aging, a detailed view is presented of the filter element "wire/glass-fibre filter" and the test oil "Mixcut LO" (mineral oil). In Figure 3 the time development of the pressure drop, the drainage, the calculated total holdup and oil holdup are shown. It can be seen, that after 120 
minutes a steady state pressure drop was reached where afterwards the nozzle spray was shut off. After 20 minutes a new stationary pressure drop was obtained and all other separation properties have reached a new steady state as well (results are given in Table 3 ).

In this new steady state the clean gas concentration was measured in four particle size fractions $(<0.3 \mu \mathrm{m},<1 \mu \mathrm{m},<3 \mu \mathrm{m}$ and $<10 \mu \mathrm{m})$ using the CYCL-FID-measurement device. Afterwards the filter was removed from the filter holder and the raw gas was also measured with the CYCL-FIDmeasurement device to calculate the fractional separation efficiencies in four particle size ranges (<0.3 $\mu \mathrm{m}, 0.3-1 \mu \mathrm{m}, 1-3 \mu \mathrm{m}$ and 3-10 $\mu \mathrm{m})$.

\subsection{Comparison of test results regarding the test oil substance}

In Table 3 to 5 the summarized results of the steady-state filtration specific properties are given for each of the three oil substances.
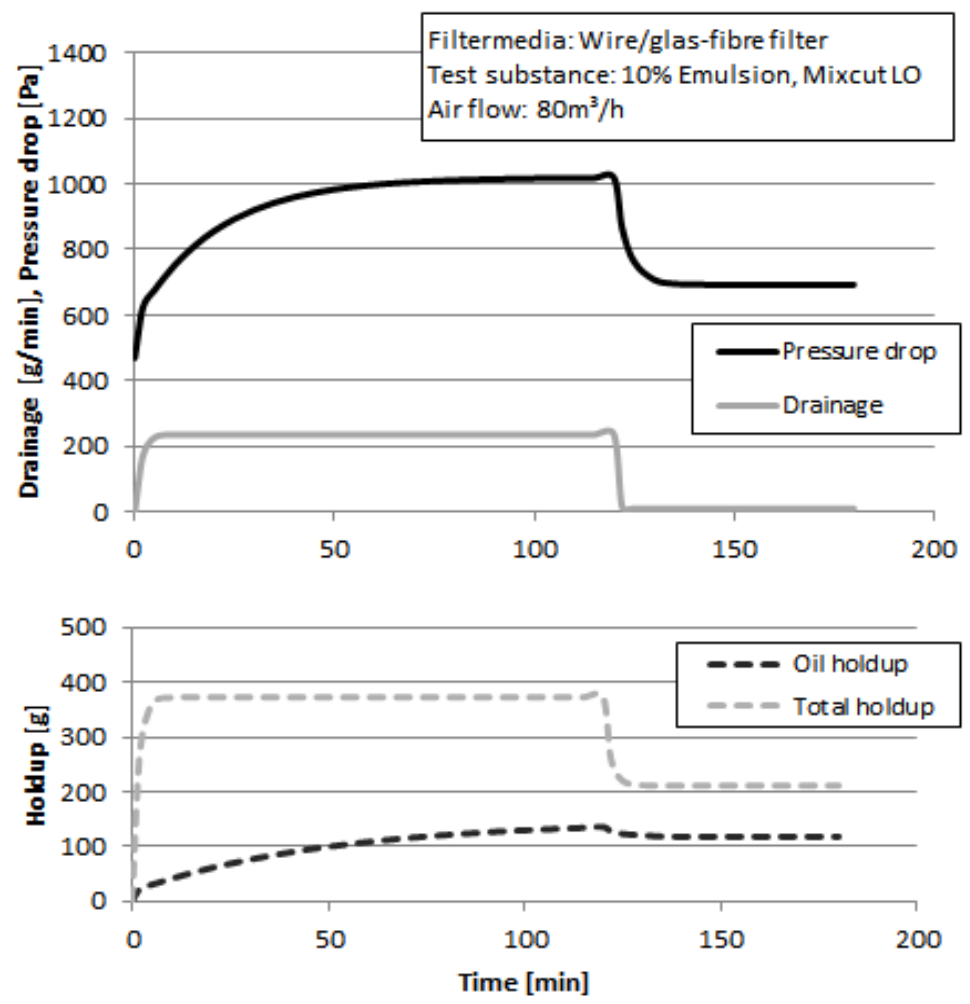

Figure 3. Time development of the pressure drop, the drainage, the oil holdup and the total holdup

Slika 3. Promena pada pritiska, odvodnjavanja, zadržavanja ulja i ukupnog zadržavanja tečnosti sa vremenom

Table 3. Summed results of the steady-state filtration specific properties with test substance "Mixcut LO" (mineral oil) as $10 \mathrm{Vol} \%$ emulsion

Tabela 3. Filtracioni parametri postignuti u stacionarnom režimu rada, primenom $10 \%$ emulzije mineralnog ulja "Mixcut LO" kao test supstance

\begin{tabular}{|c|c|c|c|c|c|c|c|}
\hline & & Baffle plate & Wire mesh & $\begin{array}{l}\text { Coarse glass- } \\
\text { fibre filter }\end{array}$ & $\begin{array}{c}\text { Fine wire/glass- } \\
\text { fibre filter }\end{array}$ & $\begin{array}{l}\text { Fine glass- } \\
\text { fibre filter }\end{array}$ & HEPA filter \\
\hline Air flo & $\left.\left[\mathrm{m}^{3} / \mathrm{h}\right)\right]$ & 200 & 200 & 200 & 80 & 80 & 80 \\
\hline & $<0.3 \mu \mathrm{m}$ & 0 & 0 & 6 & 24 & 10 & 11 \\
\hline $\begin{array}{l}\text { Fractional } \\
\text { separation }\end{array}$ & $0.3-1 \mu \mathrm{m}$ & 31 & 52 & 80 & 65 & 70 & 90 \\
\hline efficiency $\left(\mathrm{E}_{\mathrm{i}}\right)$ & $1-3 \mu \mathrm{m}$ & 98 & 87 & 95 & 98 & 100 & 97 \\
\hline & $3-10 \mu \mathrm{m}$ & 92 & 94 & 87 & 98 & 100 & 99 \\
\hline Filter-class & & 3 & 5 & 7 & 6 & 7 & 9 \\
\hline Pressure dro & [Pa] & 118 & 42 & 686 & 131 & 1186 & 669 \\
\hline Total holdup & & 46 & 48 & 213 & 528 & 258 & 16 \\
\hline Oil holdup [g & & 26 & 27 & 125 & 217 & 152 & 8 \\
\hline
\end{tabular}


Table 4. Summed results of the steady-state filtration specific properties with test substance "Mixcut UN2" (semi-synthetic oil) as $10 \mathrm{Vol} \%$ emulsion

Tabela 4. Filtracioni parametri postignuti u stacionarnom režimu rada, primenom $10 \%$ emulzije polusintetičkog ulja "Mixcut UN2" kao test supstance

\begin{tabular}{|c|c|c|c|c|c|c|c|}
\hline & & Baffle plate & Wire mesh & $\begin{array}{c}\text { Coarse } \\
\text { glass-fibre } \\
\text { filter }\end{array}$ & $\begin{array}{c}\text { Fine } \\
\text { wire/glass- } \\
\text { fibre filter }\end{array}$ & $\begin{array}{l}\text { Fine glass- } \\
\text { fibre filter }\end{array}$ & HEPA filter \\
\hline Air flow [m & & 200 & 200 & 200 & 80 & 80 & 80 \\
\hline & $<0.3 \mu \mathrm{m}$ & 1 & 1 & 19 & 13 & 8 & 14 \\
\hline Fractional & $0.3-1 \mu \mathrm{m}$ & 38 & 58 & 74 & 83 & 88 & 87 \\
\hline efficiency $\left(\mathrm{E}_{\mathrm{i}}\right)[\%]$ & $1-3 \mu \mathrm{m}$ & 93 & 95 & 98 & 95 & 96 & 92 \\
\hline & $3-10 \mu \mathrm{m}$ & 98 & 86 & 94 & 87 & 96 & 95 \\
\hline Filter-class & & 4 & 4 & 6 & 6 & 8 & 8 \\
\hline Pressure drop [P & & 116 & 43 & 667 & 123 & 1001 & 711 \\
\hline Total holdup [g] & & 53 & 47 & 213 & 528 & 258 & 16 \\
\hline Oil holdup [g] & & 14 & 7 & 55 & 151 & 72 & 4 \\
\hline
\end{tabular}

Table 5. Summed results of the steady-state filtration specific properties with test substance "Mixcut SE" (full synthetic oil) as 10Vol\% emulsion

Tabela 5. Filtracioni parametri postignuti u stacionarnom režimu rada, primenom $10 \%$ emulzije sintetičkog ulja "Mixcut SE" kao test supstance

\begin{tabular}{|c|c|c|c|c|c|c|c|}
\hline & & Baffle plate & Wire mesh & $\begin{array}{c}\text { Coarse } \\
\text { glass-fibre } \\
\text { filter }\end{array}$ & $\begin{array}{c}\text { Fine } \\
\text { wire/glass- } \\
\text { fibre filter }\end{array}$ & $\begin{array}{l}\text { Fine glass- } \\
\text { fibre filter }\end{array}$ & HEPA filter \\
\hline Air flow & $\left.\left.n^{3} / h\right)\right]$ & 200 & 200 & 200 & 80 & 80 & 80 \\
\hline & $<0.3 \mu \mathrm{m}$ & 0 & 9 & 24 & 5 & 17 & 16 \\
\hline separation & $0.3-1 \mu \mathrm{m}$ & 40 & 54 & 76 & 85 & 74 & 90 \\
\hline efficiency $\left(\mathrm{E}_{\mathrm{i}}\right)$ & $1-3 \mu \mathrm{m}$ & 89 & 86 & 94 & 93 & 95 & 97 \\
\hline & 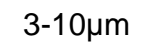 & 88 & 95 & 89 & 88 & 91 & 95 \\
\hline Filter-class & & 3 & 4 & 5 & 6 & 6 & 7 \\
\hline Pressure drop & & 119 & 48 & 675 & 182 & 1019 & 690 \\
\hline Total holdup [s & & 56 & 41 & 180 & 734 & 278 & 14 \\
\hline Oil holdup [g] & & 12 & 10 & 54 & 272 & 85 & 4 \\
\hline
\end{tabular}

Comparing the achieved final pressure drops of the six filter elements (Table 3 to 5 ), no significant influence of the cooling lubricant oil used can be seen. The fluctuations are in the range of less than $10 \%$ of the mean final pressure drop of a respective filter medium.

The comparison of the stationary total liquid holdups of the six filter elements shows no conspicuous influence of the cooling lubricant oil used, too. The only outliner is the combination "fine wire/glass-fibre filter" which has with the fullsynthetic oil "Mixcut SE" the highest total holdup and oil holdup of all tests.

Besides that, when looking at the stationary oil holdup of the six filter elements, all filter elements tested with the cooling lubricant oil "Mixcut LO" (mineral oil) reached a much higher stationary oil holdup than with the other two cooling lubricant oils. With the cooling lubricant oil "Mixcut LO", the ratio of oil holdup to total holdup is around $60-70 \%$, while this ratio is only around $40 \%$ for the cooling lubricant oils "Mixcut SE" and "Mixcut UN2".

When comparing the stationary mean separation efficiencies in four particle size ranges $(\leq 0.3 \mu \mathrm{m},>0.3 \mu \mathrm{m}$ to $\leq 1 \mu \mathrm{m},>1 \mu \mathrm{m}$ to $\leq 3 \mu \mathrm{m},>3 \mu \mathrm{m}$ to $\leq 10 \mu \mathrm{m}$ ) of the six filter media, again there is only a little significant influence of the cooling lubricant oil used. The fluctuations lie in the range of $5 \%$ of the mean separation efficiency of a certain particle size range. 
For all filter elements, it is noticeable that the separation efficiency in the particle size range " $\leq 0.3 \mu \mathrm{m}$ " is less than $25 \%$. This is remarkable because the HEPA filter (marked as $\mathrm{H} 13$ according to DIN EN 1822 [18]) should also precipitate fine droplets of less than $0.3 \mu \mathrm{m}$ in excess of $99 \%$. As the Cyclone-FID measurement method also incorporates the vapor fraction of a cooling lubrication emission into the particle size range " $\leq 0.3 \mu \mathrm{m}$ ", the low separation efficiency can be attributed to no significant vapor reduction of the filter elements.

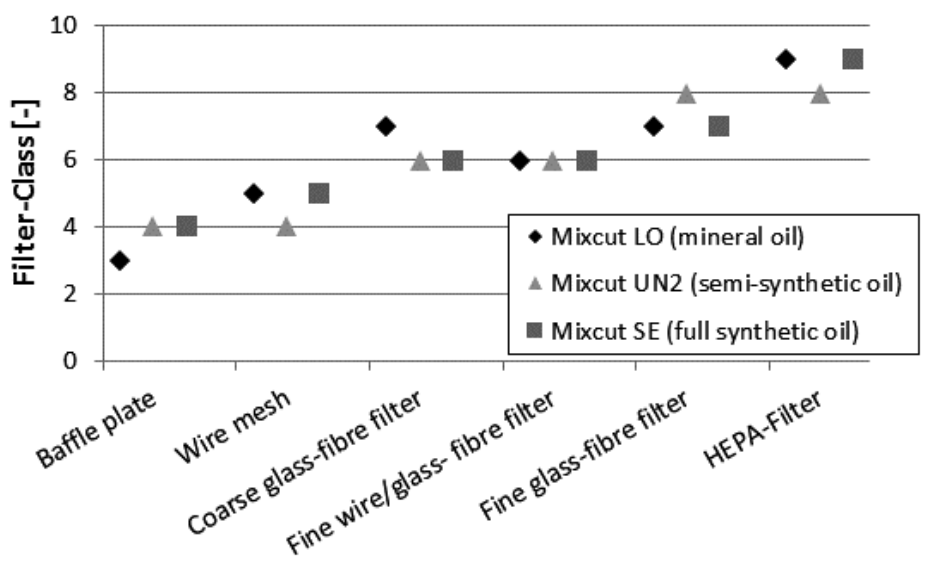

Figure 4 Comparison of the achieved filter-class of the filter elements regarding the test substance

\section{Slika 4. Poređenje postignute filter klase u zavisnosti od test supstance}

As shown in Figure 4, the pre-separators ("baffle plate" and "wire mesh") are provided with a filter-class of 3 to 5 . Finer filter elements with mainly coalescence properties (fine and coarse glass-fibre filters) can be found in filter classes 6 to 8. The HEPA filter is determined in filter-classes 8 and 9 . The influence of the coolant oil base on the filter-class is not significantly discernible. The fluctuations of the individual separation efficiency values differ of about $5 \%$, which is nevertheless enough, that the finally achieved filter-class at least results in one higher or lower filter-class number.

\section{CONCLUSION}

As a result of the investigations carried out on the influence of the test liquid oil base on the stationary filtration specific properties of six filter elements, it can be summarized that the test procedure as well as the classification according to ÖNORM Z1263 successfully succeeded.

Regarding the variation of the cooling lubricant oil bases (mineral oil, semi-synthetic oil and fullsynthetic oil), no clear trend was found in the classification of the filter media. The fluctuations of the individual separation efficiency values differ of about $+/-5 \%$.

\section{REFERENCES}

[1] W.Pfeiffer (2003) Schutzmaßnahmen beim Umgang mit Kühlschmierstoffen, Gefahrstoffe-Reinhaltung der Luft, 63, 147-152.
[2] F.Klocke, K.Gerschwiler, B.Meier (2006) BGIAReport 9/2006, Berufsgenossenschaftliches Institut für Arbeitsschutz, Germany, p.19-40.

[3] W.Pfeiffer (2006) BGIA-Report 9/2006, Berufsgenossenschaftliches Institut für Arbeitsschutz, Germany, p.9-18.

[4] T.Laminger, W.Höflinger (2010) 6th World Congress of Particle Technology, 26.-29. April 2010, Nuremberg, Germany, proceedings, p. 213.

[5] M.Boundy et al. (2009) Performance of Industrial Mist Collectors Over Time, Applied and Environmental Hygiene, 15(12), 928-935.

[6] S.U.Patel, G.G.Chase (2010) Gravity orientation and woven drainage structures in coalescing filters, Separation and Purification Technology, 75(3), 392401.

[7] P.Raynor, D.Leith (2000) The influence of accumulated liquid on fibrous filter performance, Journal of Aerosol Science, 31(1), 19-34.

[8] D.Kampa, S.Wurster, J.Buzengeiger, J.Meyer, G.Kasper (2014) Pressure drop and liquid transport through coalescence filter media used for oil mist filtration; Journal of Multiphase Flow, 58, 313-324.

[9] P.Contal et al (2004) Clogging of fibre filters by submicron droplets. Phenomena and influence of operating conditions; Journal of Aerosol Science, 35(2), 263-278.

[10] ÖNORM Z1263:2013. Separators for cooling lubricants - Requirements and classification. Austrian Standards, Vienna, Austria.

[11] W.Höflinger, B.Neumann (2003) Verfahren und Vorrichtung zur Ermittlung der Eigenschaften von Kühlschmierstoffen. Patent DE102004050372 A1.

[12] W.Höflinger, P.Wlaschitz (2005) Verfahren und Vorrichtung zur Bestimmung der bei Kühlschmiervorgängen in die Atmosphäre emittierten Anteile an Schmierstoffen. Patent EP1757927 B1. 
[13] W.Höflinger, T.Laminger (2009) 8th World Congress of Chemical Engineering, 23.-25. August 2009, Montreal, Canada, proceedings p.265.

[14] T.Laminger, M.Stecher, W.Höflinger (2012) Method of testing metal working fluid mist separators, Filtration 12 (2), 120-128.

[15] OMV AG (2009) Product safety data sheet "Mixcut LO" PNr. 181031.
[16] OMV AG (2009) Product safety data sheet "Mixcut UN2" PNr. 181037.

[17] OMV AG (2009) Product safety data sheet "Mixcut SE" PNr. 181080.

[18] DIN EN 1822-1:2011-01. High efficiency air filters (EPA, HEPA and ULPA) - Part 1: Classification, performance testing, marking. Beuth Verlag, Berlin, Germany.

\section{IZVOD}

\section{UTICAJ TEST EMULZIJE NA EFIKASNOST FILTRACIJE I PAD PRITISKA KOD FILTERA ZA UKLANJANJE AEROSOLA FORMIRANOG OD SHP SREDSTAVA}

Ovaj rad se bavi standardizacijom procedure za ispitivanje filtera za separaciju tečnog aerosola formiranog od SHP sredstava u radnoj sredini mašina alatki. Austrijski standard ÖNORM Z1263 opisuje opremu za ispitivanje aerosol filtera, postupak njihovog ispitivanja, kao i način njihove klasifikacije. Prateći ove smernice šest filtera različite konsutrukcije i materijala, koji se primenjuju u industriji testirani su u cilju određivanja filtracionih parametara, kao što su: pad pritiska, ukupno zadržavanje tečnosti u filteru, zadržavanje ulja u filteru i efikasnost separacije. Na osnovu efikasnosti separacije testirani filteri će se klasifikovati u određenu klasu filtera od 1 do 10.

Standard ÖNORM Z1263 ne definiše test supstancu, tako da postoji interes za proučavanje uticaja različitih test supstanci. Kao test supstance ispitivana su tri ulja koja se koriste $u$ industriji: mineralno ulje, polusintetičko i sintetičko ulje. Ova ulja se primenjuju kao emulzije, i spadaju u grupu SHP sredstava. Šest filtera je testirano po ÖNORM Z1263 standardu. Upoređivanjem dobijenih rezultata primenom različitih test ulja, odnosno njihovih emulzija uočava se se da ne postoji značajan uticaj ulja na klasifikaciju filtera. Postignuta klasa filtera se samo u pojedinim slučajevima razlikovala za jednu klasu, što je zanemarljivo sa obzirom na usku granicu među klasama.

Ključne reči: sredstva za hlađenje i podmazivanje (SHP), emulzija, aerosol filteri, efikasnost separacije, pad pritiska, testiranje filtera.

Naučni rad

Rad primljen: 29. 05. 2017.

Rad prihvaćen: 17. 08. 2017.

Rad je dostupan na sajtu: www.idk.org.rs/casopis

(c) 2017 Authors. Published by Inženjersko društvo za koroziju. This article is an open access article distributed under the terms and conditions of the Creative Commons Attribution 4.0 International license (https://creativecommons.org/licenses/by/4.0/) 